I Universidade Estadual de Campinas (Unicamp), Department of Sociology,

Postgraduate Program in Sociology, Campinas, São Paulo, SP, Brasil

chaguri@unicamp.br

https://orcid.org/o0oo-0002-520I-360X

I I Universidade Estadual de Campinas (Unicamp), Postgraduate Program

in Sociology, Campinas, São Paulo, SP, Brasil

Mariana Miggiolaro Chaguri'

flaviapaniz@gmail.com

Flávia X. M. Paniz"

https://orcid.org/00oo-0002-2056-1636

\title{
WOMEN'S WAR: GENDER ACTIVISM \\ IN THE VIETNAM WAR AND IN THE WARS \\ FOR KURDISH AUTONOMY ${ }^{1}$
}

\section{INTRODUCTION}

Those who would codify the meanings of words fight a losing battle, for words, like the ideas and things they are meant to signify, have a history

(Joan Scott).

This paper discuss women's activism in two contexts of war, focusing on their participation in the Vietnam War (I954-I975) based on a research carried out by Mariana M. Chaguri in the archives of the Vietnamese Women's Museum in Hanoi $^{2}$ and in the Kurdish struggle for autonomy, studied in the doctoral research currently being undertaken by Flávia X. M. Paniz, who is working with local and transnational Kurdish women's organizations in London.

Referring to women's participation in these two wars - one of them still in course - immediately refers to the symbolism usually implicit in debates on wars, that is, an allusion to the idea that war is primarily masculine, waged by men, thus allowing women just to participate in it. Exploring a similar topic, Svetlana Alexievich reconstructs the memory of women's participation in the Red Army during the Second World War (I939-I945), observing that

There have been a thousand wars - small and big, known and unknown. And still more has been written about them. But... it was men writing about men that much was clear at once. Everything we know about war we know with "a man's voice". We are all captives of "men's" notions and "men's" sense of war. "Men's" words. Women are silent [...] When women speak, they have nothing or 
almost nothing of what we are used to reading and hearing about: How certain people heroically killed other people and won. Or lost: What equipment there was and which generals. Women's stories are different and about different things. "Women's" war has its own colors, its own smells, its own lighting, and its own range of feelings. Its own words (Alexievich, 2018: 23-25, our emphasis).

What it is at stake here is not essentializing and superimposing subject and origin by naturalizing categories of representation such as "male" and "female". Instead, the author draws our attention to how gender pervades what may be taken usually as an universalizable narrative about war. By adressing women's experience in war and their narratives about it affords the possibility of "redefining and enlarging traditional notions of historical significance" (Scott, I986: I054). ${ }^{3}$

This wider approach entails the theoretical and empirical articulation of "gender", "nation", and "war". Indeed, the literature on these topics4 includes some substantial reviews, such as the book Feminism and war: confronting US

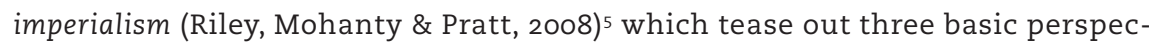
tives on the articulation of these topic within literature, namely: (I) the contrast between masculinities and militarisms, symbolized by the use of force, and the correlation of femininity with pacificism as a premise symbolically representative of women, usually opposed to war; (2) the double role played by the rhetoric of women's rights and freedoms, used to justify foreign occupation of peripheral countries (and the work of international organizations in these spaces), and to justify discriminatory policies at domestic level; and (3) an ambivalence concerning racial and gender mediations, in which we find the American foreign war policy characterized on the one hand by the military actions of white men, and their respective rhetoric that support salvationist and civilizatory missions which liberate women of colour (black, brown, yellow etc.) in peripheral countries and/or women from ethnic minorities, and on the other hand, national domestic policies that criminalize and marginalize men of colour, defending white women's freedom as a main argumentative strategy.

Comparing the articulations among gender, nation, and war examined in this paper enables us to point our two distinct modes of representing and mobilizing the agency of peripheral women in war contexts that converge on a central point: women's agency in these contexts involves tensions and negotiations over the definitions of what is "public" or "private": within a nation.

Hence, in the dynamics of the struggle marked by gender activism (Badran, 2009), the correlation between the national and the domestic must be retought. In the case of Vietnam, for instance, the representation of the role of caring for the home and family becomes a synonym for caring for the nation. In their turn, the Kurdish women involved in the war performed a double role through their dispute for symmetrical power and spaces of leadership within the Kurdish struggle itself, and its reorganization of collective life (again cor- 
relating the internal space of the nation with domestic space), and through their external activities in the armed militias on the frontline of combat with enemies (against ISIS, the Turkish Gendarmerie and other paramilitary groups operating in the region).

The results of our research show a collective endeavor to produce other narratives of visibility concerning the participation of women in the conflicts, shifting the role performed by them towards an effective contribution symmetrically equal to men's. To this end, at least two movements have been undertaken: (I) the enlargement of spaces for debates on gender in research, archives and museums on war contexts by making visible women's activities and demands; (2) the production of distinct narratives - theoretical, museological, literary and visual - about war, thus making it possible to observe how discussions on gender issues appear only when women's participation is mobilized.

However, it is not a case of "prov[ing] either that women had a history or that women participated in the major political upheavals of Western civilization" (Scott, I986: I055), but rather of pointing out that their experiences, participations and demands lived for a long time on the fringes of the production of ideas and the ways in which nations were imagined. ${ }^{6}$

Consequently, the first effort to break the silence must be in the theoretical dimension by expanding concepts and categories to cope with a heterogenous set of feelings, notions and ideas that mark women's participation and activisms. Moreover, there must be concepts and categories able to name different forms of violence (Das, 2007) and to offer new selective and differentiated framings about women and about wars themselves (Butler, 2015).

With this aim in mind, it is crucial to observe that a key element of the modes of perceiving, telling and making visible women's participation in wars are their shared experiences which makes it possible to explore processes of differentiation and identification, both central to the constitution of a collective action and of forms of activism.?

Regarding this paper, the comparative analysis of different times, spaces and contexts of war will show how the reorganization of gender roles draws the meanings of wars and configures what we call a woman for the times of war, that is, a woman who moves across spaces of public confrontation, armed conflict, and domesticity. Also, in war contexts, the clash between the public and private spheres that defines the feminine differently (Perrot, I998; Scott $\&$ Keates, 2004) are remade or repositioned - depending on the case.

\section{WOMEN'S ACTIVISM IN VIETNAM}

Here we reconstruct the mobilization and participation of Vietnamese women 8 in the Vietnam War and some earlier conflicts, as the French Indochina War (I946-I954), through a set of manifold documents that ranges from posters, photos, newspapers of that epoch, to letters, diaries, and interviews. A major 
part of this material is in the collection of the Vietnamese Women's Museum, responsible for safeguarding the material and displaying part of it in a permanent museum exhibition. Both will be analysed throughout this paper.

The temporalities, spatialities, and demands that underpin these mobilizations are diverse, because they cross over wars, conflicts, and disputes that left thousands dead and injured, and marked the trajectories and experiences of families, individuals, the State itself and its territory. In what follows, many fronts and networks of women's activism converge indirectly and directly on countless battlefronts.

From the I930s and on, different groups of women, schooled or not, established initiatives and funds for actions in areas including social welfare, political mobilization around a variety of entities like the Communist Party of Vietnam (CPV), local community associations or professional orders, especially lawyers and journalists. This way, different anticolonial and, gradually, antiimperialist causes gathered together in organizations, such as the Women's National Salvation Group, Women's Association for Liberation, Women's Association for Democracy, Women's Association for National Safety, and Women's Anti-Imperialist Association.

A fundamental point of reference for the activism of this period is the foundation of the Women's Union (WU) in I935. Linked to the CPV, founded just five years earlier, a significant number of the associations cited above converged on the leadership of the WU, which brought together a heterogenous set of women's associative activities, ${ }^{9}$ fostering a gradual articulation for anticolonial struggle, communism and female autonomy. In particular, it created objective possibilities for the stabilization of a network of associations that supported the actions and struggles of women until (at least) I975, when the country was reunified.

Over the years, although their activities remained diverse, one observes that women's demands increasingly orbit around three elements: people, sovereignty, and cultural heritage/legacy. Such notions have been disputed and reconstructed after 1975 when the Vietnamese nation became "imagined" primarily through the activism surrounding the CPV.

Regarding the issues discussed here, we suggest that gender and nation became disputed terms within this network of activisms. Both terms defined and problematized each other. Gender regards not only women, but also masculinities - which, in this case, entails the destabilization of the association among war, virility, and the defense of national sovereignty.

The polarity between gender and nation not only affords meaning to the terms gender and nation, but also converts them together into categories for the political mobilization of women insofar as it enlarges the meanings attributed to the notions of people, sovereignty and cultural heritage/legacy. In this manner, it promotes new axes of differentiation that, in a way, reposition gender roles. 
Analytically, ideas regarding people, sovereignty and cultural heritage/ legacy also turn to be characterized by attributes like care, patience and perseverance, what rearticulated the shared experiences of women, whether peasants, workers or liberal professionals. Nay, their domestic roles as wives, daughters or mothers gain strength when shaping a woman for the times of war, because it means that they were the ones who provided patient and tenacious protection for the family and, at a large, for the defense of the nation.

In this sense, gender and nation come to qualify each other insofar as the latter also transforms into the extended family of all those involved in the war effort, amplifying the ties of solidarity, the possibilities and range of mobilization. There are two key contexts for this.

The first, between I 946 and I954, known as the "period of civil resistance", ${ }^{\text {, }}$ strengthened the networks of women's activism created in the previous decade, which spread over the north of the country through campaigns like 'Winter clothing,' 'Gold piece for saving the nation' and many other rice donation campaigns - most of them happened under the leadership of Ho Chi Minh.

During this period, woman used to raise, feed and dressing people, especially the men at the fronts. These key activities were characterized by gender roles associated with care. Although a significant number of women also took part in combat, ${ }^{\mathrm{II}}$ they performed just complementary roles. Thus, associations between feminine and care and, the masculine and force were common.

Nonetheless, women's activism also points to fairly unexpected dimensions in terms of the range and impact of this kind of collective action. In the case at stake, women carry out a network to convey objects, food, resources and information, which, in this particular context, had the unequalled capacity to articulate local and regional bodies with the national command. Thus, it enabled to create political and cultural spaces previously non-existent or quite invisible.

These spaces were fundamental to the mobilization and confrontation within conflicts and disputes that began in I955 with the outbreak of the armed conflict with the United States.

A year earlier, in 1954, the Geneva Conference brought to an end the Indochina War (I947-I954) and divided the Vietnamese territory into two zones. In the north, the Democratic Republic of Vietnam and in the south, the Republic of South Vietnam. The first had its capital in Hanoi, it was proclaimed eight years earlier, in 1946, in the wake of the ample Vi t Minh movement of national liberation led by Ho Chi Minh. While the agreement marked the consolidation of the Democratic Republic of Vietnam and the anticolonial struggle against the French, it also founded the State of Vietnam in the zone to the south, under the leadership of the former emperor B $\circ \boxplus i$. A little more than a year later, in November I955, $Ð$ i was deposed and the Republic of South Vietnam was proclaimed under the leadership of Ngô Đình Di m with its capital in Saigon, today Ho Chi Minh City. 
In the Cold War context, the political and military disputes between the two zones of the Vietnamese territory quickly escalated, aligning the superpowers of the USSR and the USA with the forces of the north and south, respectively. The conflicts steadily intensified and the US military forces began to fight on land against the national liberation forces organized in the north under the leadership of the CPV and Ho Chi Minh. ${ }^{\text {I2 }}$

After that, the scope of women's activism and mobilization expanded significantly. This included not only their substantial participation on the battlefronts, but also the complexification of the previous network. The network grew beyond the earlier campaigns focused on caring for troops and it embraced political and cultural initiatives, as well as an international solidarity initiative driven by the attempt to challenge the (mostly) foreign narratives and perceptions about the war. ${ }^{\mathrm{I}}$

The robust chain of face-to-face contacts built by the earlier activism increasingly became associated with new kinds of mobilizations, led by a generation of women who were mostly training or had trained in universities. Women also started to join war because and their professional positions, what broadened the possibilities for competing for the production and circulation of ideas that helped ascribe meaning to the conflict and to issues and values at stake.

These women were students, journalists, lawyers, and teachers (mostly but not only) who organized associations analogous to local committees of women student's movements - one of the most prominent being the "Saigon movement". Other associations formed during the period were the Women's Committee for the Right to Live in Peace and Dignity, and the Vietnamese Women Demand Living Rights, as well as hundreds of local Women's Union committees. Even, editorial initiative has spread around, such as the Women's Voice and Speech newspapers, along with the production of propaganda material, books and leaflets especially designed to mobilize women (see Do Thi \& Brennan, 20I5). It is worth emphasizing, however, that the previous activism associated with the sphere of care did not vanish, but gathered momentum, especially through the strengthening of initiatives like the innumerable local and regional committees of the Soldier's Mothers Associations. ${ }^{\text {I4 }}$

After I I years of conflict, women's activism was reorganized and acquired a new center of gravity, the Three Responsibilities Movement, launched on March 22, I 965 during the Women's Union Annual Congress. The launch was made in the presence of Ho Chi Minh whose speech extolled Vietnamese women as "heroic, indomitable, faithful and responsible" (see the exhibition at the Vietnamese Women's Museum).

The three responsibilities evoked in the movement's name were to: I) fight against the enemy (by performing support functions or at the front), while also encouraging men from the family to do the same; 2) engage in agricultural or industrial production; 3 ) continue to provide care to the family, sup- 
porting elderly members, educating children and feeding family members (Werner, 2009). According to the accounts of CPV militants of the archive of the Vietnamese Women's Museum, the Three Responsibilities Movement's membership extended to around I.7 million Vietnamese women (folder 98, document 234). Amid this movement, the first of the three responsibilities began to increase as the years passed and the conflicts intensified, fomenting the organization of female battalions that became part of the People's Army. ${ }^{15}$

Significant examples include the Dong Phuong Hong Women Military Platoon (founded approximately in I 964 with 32 women), the Luoi Guerrilla Group (composed of I6o women), the Long-Haired Army (which formed part of the National Liberation Front in zones controlled by the United States in Saigon), and the Ngu Thuy Female Artillery Company (active between I967-I977 and having as many as 98 combatants) (Giáo, 2008: I52-I53). ${ }^{16}$ Another significant women's movement during the period was the Anti-American Young Volunteers Force, responsible for the mobilization of approximately 60,000 women dedicated to repairing roads after aerial bombardments, providing medical care, establishing communications between battalions and troops, and driving combat trucks transporting weapons or soldiers (injured or not).

Between February and October I968, there was an intense escalation of the conflict by US armed forces, which launched the Toan Thang (or Complete Victory) Operation, and Vietnamese forces through the Tèt Offensive. The intensification of the conflict, as well as the increase in the networks of international pressure to end the war, led the US president Lyndon Johnson to order, in March I968, a scaling back of the bombing of north Vietnam and a complete ceasefire in the region in October the same year (see Nguy n, 2017; Logevall, 2018).

As indicated above, the Vietnam War was marked by the organization of a broad network of women's activisms through which letters, documents, weapons, ammunition, medicines, and food were conveyed (Giáo, 2008). It was in I968, however, that the presence of women on the different fronts became widespread and they began to occupy the battlefronts in large numbers, as revealed, for example, by the actions of the Trang Liet Women's Guerrilla Group and the 8th March Women's Artillery Group, whose war efforts included shooting down US airplanes and retaking relevant territories (see the exhibition at the Vietnamese Women's Museum). Not by chance, by taking part in major acts of war like shooting down airplanes, for instance, the months of April and May I968 became known in Vietnam as the Spring of Women (Giáo, 2008: I64).

According this paper's, we have indicated the main types of activism regarding the participation of Vietnamese women in the conflicts fought in their territories, especially between the I930s and I970s. We now turn to an analysis of aspects of conflicts linked to the Kurdish Question, in order to interpret these activisms and participations in a comparative analysis by laying full stress to a common dimension: the construction of an ideal of "woman for times of war". 


\section{WOMEN'S ACTIVISM IN KURDISH CONFLICTS}

Although a substantial document archive exists at the Institutes of Kurdish Culture in Paris and Brussels and the European Centre of Kurdish Studies, located in Berlin, there is no museological narrative at a national level specifically addressing Kurdish women's activism, as in the case of Vietnam. This may be because the conflicts remain ongoing, or because the narratives themselves on the history and protagonism of these women are a matter open to dispute. Consequently, the sources used for this analysis come from digitized documents in the archives, materials produced and/or disseminated by different Kurdish women's organizations in the media and on social networks (texts, images, and videos), accounts gathered through interviews, and an analysis of the literature on the theme.

The conflict known as the Kurdish Question began in the second half of the Igros with the signing of the Sykes-Picot Agreement (I9I6), followed by the Treaty of Sèvres (I920) and the Treaty of Lausanne (I923), which, among other things, redivided the territories predominantly inhabited by Kurdish communities among four emerging countries: Iran, Iraq, Syria and Turkey (Mojab, 200I). The conflict reaches the present moment and it had diverse repercussions, including the foundation of the Iraqi Kurdistan Regional Government, the fight for autonomy in regions, such as Kobane, Afrin and Raqqa, and the dynamics of the fight for rights in the contexts of the abovementioned States.

The time span covered by the analysis in this paper, however, commences in the I970s, the period when women's protagonism began to be included as a topic of study and analysis within the broader context of the conflict's history. This does not mean women did not effectively participate in earlier conflicts, but it is from this period onwards that the silence about their participation was broken, and their activities became registered as effective within the militant spaces (Dryaz, 20I I).

In the historiography of the Kurdish struggle over the course of the 2oth Century, competing narratives appeared regarding the notions of territory, time, people and their respective political agendas. Nevertheless, all of them can be synthesized through some shared characteristics of most of the reference works. They are (a) the importance of recognizing ethnic, cultural and religious heterogeneity among the region's diverse Kurdish minorities, and (b) the disputes concerning the meanings of the ideals of freedom.

The historiographic debates about the conflicts in the first half of the 2oth Century are marked primarily by reflections concerning the recognition of their territorial autonomy; a right based on the argument of the ancestral inheritance of the land (Yildiz, 2005). The formation and respective independencies of Iran, Iraq, Syria and Turkey as nation states initiated a series of measures aimed at expropriating land from Kurdish communities, especially in I945, the period when the conflicts for the territories broadened and intensified. 
With the expropriation of land, the absence of constitutional recognition and the consequent marginalization of diverse ethnic minorities, the Kurds among them, ethnicity became integral to the dynamic of disputes for rights within the States.

The proclamation of the Self-Determination of Peoples, one of the principles outlined in the Atlantic Charter of I94I and ratified in the Charter of the United Nations in I946, promoted an international political context favorable to a policy in support of the freedom and ethnic autonomy of diverse peoples in conflict situations. When it came to the Kurdish Question, the defense of an idea of the Kurdish people emerged and began to find the central argument of their ceaseless struggle for autonomy. One observes this movement, for instance, in the document "The Kurdish Question", produced by W. G. Elphinston (2009), an officer of the British intelligence service for the Middle East, in which he drew on the Atlantic Charter to request a solution from the UN to promote the freedom of the Kurdish peoples.

In the document, Elphinston emphasizes what, in his view, were the qualities of the Kurds as a people, such as their own literary production, their own social, cultural, religious and political organizations distinct from other ethnic groups, and archaeological evidences that corroborated the historical presence of the Kurds in the region (Elphinston, 2009). ${ }^{\text {I7 }}$ The disputes surrounding a representative idea of the Kurdish people are discussed in the study made by Strohmeier (2003), whose research showed how the production of this category enabled diverse reflections on political hierarchies and dynamics related to the access and representativity in the Kurdish publishing market, fomenting the critique of a supposed condition of Kurdish ethnic homogeneity.

The defense of the idea of a Kurdish people as a political movement is undone as the ethnic, cultural and religious multiplicity of the different Kurdish and non-Kurdish communities becomes recognized, along with the respective impacts of their relations in the region after the I960s (Strohmeier, 2003; Yavuz, 2004: I26). Hence, the hypothesis defended here is that the debates on gender emerge as a possibility for reorganizing the common political agenda in the 2 Ist Century, claimed by different women's collectives and organizations, which has enabled a new approximation between Kurdish communities that had branched out, especially from the I970s onwards.

The production of a new relationship between gender and nation, which has been fomented within these collectives and organizations, is promoting a renegotiation of the meanings of the very idea of freedom in order to frame the political agenda of women as an issue central to the struggle for autonomy of all Kurdish communities. This movement has been possible thanks to three main elements: (I) the movements of Kurdish women in local bodies, such as armed organizations, political parties and diverse community associations, followed by men joining; (2) a favorable international context in which issues re- 
lated to gender, feminism and women's reorganization against diverse forms of violence have given rise to new ways of looking at politics, at the media and at social, labour and family relations; (3) the articulation between local and transnational organizations driven principally by the intellectual production and activism produced in the diaspora.

It should be observed, however, that differences within the communities themselves produce distinct hierarchies and expectations, whether in the dynamics of the fight for autonomy or in the debates on broadening rights and ethnic recognition within the nation-states constituted in the region. In any event, the meanings of the idea of freedom for the different women's collectives and organizations started to become disputed. Consequently, the ideas of freedom, in the context of the dynamic of the conflicts over Kurdistan, became relational and contextual, having to encompass multiple meanings, depending on where, how and by whom they are enunciated.

In the second half of the 2oth Century, the political organizations of the different Kurdish communities developed chiefly in the set of relations established with the respective States contained in their territories. In this context, different political parties, collectives and groups were formed, such as the Justice Party (Adalet Partisi/AP) (I960-I980), the True Path Party (Dokru Yol Partisi) (I983 to the present), the Democratic Union Party (2003 to the present) and the Justice and Development Party (Adalet ve Kalkınma Partisi/AKP) (200I to the present). They also included those groups that joined political movements on the borders of Iran, like Kurdish Hizbullah (Army of Allah) (KH), and those that followed a Marxist strand, like the People's Toiling Party (Halkın Emek Partisi/HEP) (I990-I993), Democracy Party (Demokrasi Partisi/DEP) (I993I 994), People's Democracy Party (Halkın Demokrasi Partisi/HADEP) (I994-2003), Democratic Society Party (Demokratik Toplum) and Kurdistan Workers Party (PKK) (Heper, 2007: I I4).

According to Heper, the latter organization, the PKK, was founded in the I 970 s by a group of young left-wing intellectuals from Ankara, among them the political scientist and Kurdish activist Abdullah Öcallan, who also helped found the Kurdistan Liberation Front in I984. After circa nine years of men and women disputing agendas within the PKK, the women from the party founded, in I987, the Patriotic Women Union of Kurdistan (YJWK), which later adopted the name Free Women's Movement of Kurdistan (TAJK) (Dryaz, 20I I). The women's movements thus grew from the denunciations of men's "sexism, patriarchalism and chauvinism" (used here as emic categories) by women from the PKK and their need to organize themselves in autonomous form (Mojab, 200I). Gradually, women started to produce manifestos and organize meetings at national congresses. In I995, the Union of the Free Women of Kurdistan (YJAK) was founded, the first official military and political organization of Kurdish women. Five years later, in I999, on the occasion of the National Meeting of 
Women on the March, the organization would become autonomous from the PKK, adopting the name of the Women Workers' Party of Kurdistan (PJKK).

In his study on the emergence of women's participation in the Kurdish conflicts, Massoud Dryaz (20I I) argues that Abdullah Öcalan, leader of the PKK, had revisited his writings on the movement and oriented the restructuring of the party's agendas to promote an egalitarian political approach to gender debates. According to the author, the rumor was that this change had been influenced by his wife, Kesire Ylldırım, a member of the PKK's central committee until I983. Öcalan was captured in Kenya and handed over to the Turkish state forces in 1999. After that, he had been kept in a maximum security prison on the island of mrall, from where he wrote his texts. His books, Prison writings: the roots of civilisation (2007), Prison writings volume II: the PKK and the Kurdish question in the 2 Ist Century (20II) [2008], Democratic confederalism (20I I), Manifesto for a democratic civilization (20I5) and Liberating life: women's revolution (2018) [2016] present his reflections on the elaboration of a political model that meets the historical specificities and demands of the peoples who inhabit the regions mostly recognized as territories with Kurdish majorities, placed in the border region which divides Syria and Turkey. Recently, he also has been addressing the freedom of women as a central point of his argument on the autonomy of Kurdish peoples.

Öcalan's works and face compose the backdrop to the sets of photographs and texts disseminated by the websites of the female Kurdish army units from the north of Syria (YPJ) and the male units (YPG) today, as well as the centres of solidarity and support for the Kurdish peoples. Besides that, he is present in the texts of activists like Dilar Dirik (2005), who refer to him as the mentor of the contemporary Kurdish struggle.

In 20I4, the female Kurdish army units became known for their direct armed confrontations with the terrorist group known as the Islamic State (ISIS). However, the formation of female battalions had begun in 2012 and their goals went beyond retaking their territories and expelling ISIS from the region: they sought to promote political autonomy in the regions of Kobane, Afrin, Jinwar and Raqqa. As well as the YPJ, there are diverse other cores of women's resistance, such as the organizations composed of Yazidis women, and other women's associations whose activities are not limited to the armed struggle, like the Saturday Mothers movement, and/or those that do not necessarily identify with the causes promoted by the aforementioned organizations, like the different Kurdish feminist movements and groups of Iraqi Kurdistan and Iran.

Specifically addressing the women's organizations in Kobane to the north of Syria, however, the focal point of the present analysis, the proclamation of the canton's autonomy by them in October 20I4, along with the organization of local councils run by the women, were an outcome of demands for power symmetry between the categories of ethnicity and gender in the articulation of Kurdish national policy. 
According to the women, in the traditional agenda of the Kurdish political movements, predominantly organized by men, women's freedom was projected to a post-independence future. According to the study made by Mojab (200I), the women also pointed out that Kurdish men from the PKK made pacts agreeing to promote the re-Islamization of women during negotiation processes for the release of political leaders and campaigns in the I970s. Thus, making women's political demands effective necessarily involved convincing men about their own needs. Tired of their causes being conditional on convincing men, and also concerned by the intensification of violence against women and children in the region, women recount that they decided to take up arms to defend their own bodies.

In this context, the base of the Kurdish national political cause has become reworked, and gender equality has turned into a foundational premise. The slogan Jîn, Jyîan, Azadî (women, life, freedom) became the tripod of the nation and its politics, a mark of the process of converting the women's cause into a collective cause, instituting a notion of equality between national freedom and the freedom of women.

Thus, democratic confederalism and libertarian municipalism - models of political organization elaborated by Abdullah Öcalan and organized politically through the Democratic Union Party (PYD), TEV-DEM and other local organizations - take as fundamental premises for the construction of a statelessnation, gendered and ecologically driven, whose local political directives are produced through collective consensus. Fomented by theoretical and epistemological debates, focused primarily on postcolonial and anticolonial politics, the Jineology Centre was founded on January 2, 2018, in Manbij. The institution's objective is to promote a scientific epistemology designed to reflect on debates on the importation, appropriation and negotiation of philosophical and political categorizations and to elaborate collective projects that meet the demands corresponding to the context and the social, cultural and political specificities of Kurdish women's experiences.

Today, jineology workshops are run in various countries, including Argentina, Colombia, Holland, the UK, Chile, France, among others, by activists and intellectuals involved in the dynamics of the Kurdish women's struggle in their different contexts. ${ }^{18}$ The material produced by those women has been translated into English, Portuguese, Spanish, German, French and other languages, showing that the activism produced in the Kurdish diaspora goes beyond the frontiers of the conflict and has reconfigured its spatial dimension to encompass the transnational field. The circulation of texts and images on the activities of Kurdish women reflects the amplification of the space of war to virtual social networks, making cyberactivism a fundamental medium in the dynamic of divulgation and the search for political support among the international community. 
According to the study conducted by Ann-Kristin Kowarsch and Nursel Kilic (2007) on the traumatic experiences suffered by Kurdish women emigrating to the European Union and the psychological consequences of their ordeals, the collective sharing of experiences of violence helped produce closer bonds between them. This sense of collectivity provides insight into the factors that led to the joint construction of women's demands. The act of sharing feelings can be identified as a factor explaining the collective association of women who respond conjointly to physical, political and moral violence. In the case of Kurdish women, the naming of violence, the women argue, set off a reflection on the asymmetries between ethnicity and gender within the national narrative on the Kurdish movements and the dimension of the new context enabled the reorganization of these experiences in their memories and narratives, reconstructed, as Avtar Brah (2006) suggests, through the relations established between the originary social fabric and the fabric established in the new country.

There are many academic productions in the field of 'Kurdish Studies' based at the School of Oriental and African Studies at the University of London, at the Universities of Exeter, Sussex and Middlesex, and in the transnational network of researchers on the theme, the Kurdish Studies Network, which has more than I,300 members. In this way, the production of a Kurdish diasporic intelligentsia has become the central axis for the circulation of ideas and the production of debates aiming to break with the Orientalist, Arab-centred, Islamiccentred perspectives prevailing in the historiographic production on the Middle East over the 2oth Century. Recent research on the interface of gender studies and Kurdish studies has, in turn, looked to construct a historical narrative that shifts the role of women from the category of participation, treated as lateral and complementary, to fundamental within the context of the nation (Al-Ali, 2007).

\section{BEYOND VIETNAM AND KURDISTAN: WOMEN IN WARS AND THE WARS OF WOMEN}

Throughout this article, we have made some observations on the participation of women in the Vietnam War and the war for Kurdistan, highlighting the amplitude and variety of their forms of activism. Despite the significant contextual differences between the two cases, it is worth emphasizing a similarity between them: the polarity between gender and nation helped to shape how the wars were lived, perceived and narrated.

Even when fighting against the same enemy, the participation of women in the conflicts demonstrates that they move through a war that had its own temporality, traverses diverse spatialities and it is mobilized via a network of relations and activisms with a local diffusion and a transnational range.

Shared experiences of women in Vietnam or the different Kurdistan cantons and their diasporic communities are rearticulated by the conflicts, producing specific axes of differentiation that somehow reposition gender roles. 
This is evident, for instance, when we take the Vietnamese Three Responsibilities Movement or the Kurdish slogan Jîn, Jîan, Azadî (life, woman, freedom). In both cases, the intersection between the time of the front and the time of care craft the modes and meanings of the participation of women in war by organizing agency and producing experience. Similarly, the women who participate in war are permanently moving between spaces of public disputes, armed conflict and domesticity, whether in reference to direct care of their own home or of family members, or in a kind of domestic space remade on the fronts which involves caring for the injured, producing food, organizing arsenals, documents, uniforms and so on.

Both in Vietnam in the mid 2oth Century and Kurdistan at the beginning of the 2 Ist Century, the heterogeneity of spacialities and temporalities that marks women's activism by producing a "woman for the times of war" with specific moral obligations and attributes. It helps to produce a transnational movement.

By taking the first consequence, the "woman for the times of war", we observed that the Vietnamese women had three responsibilities during the war period: fighting, producing and caring. For that, they must gender roles that, at once, draw from the traditional associations between the "female" and "care", and highlighted the non-separation between domestic and public spheres. One can read this convergence as a contingency of the times of war, which enforce woman of all ages, family backgrounds and kinds of life to engage in the national war endeavour.

Coined by Ho Chi Minh, the movement's slogan, "good at housework and working for the state," provides an insight for reshaping gender roles in Vietnam under the CPV's leadership - that is, women equally available for the work at home or for the State. However, the equivalence in value between them, instead of entailing gender equity or an equal relationship, it indicates that fighting, producing and caring turn to be interconnected parts of the same responsibility that women had in relation to the nation.

In the case of the conflicts over Kurdistan, it is not a question of the shift between private life and public life, but the reconstruction of an ideal of a global liberational subject through images of Kurdish women. War, episodes of violence with the communities and the fear of genocide forced women to organize their resistance which led a rework of the concept of life rooted in the life of women, as well as national freedom itself. The latter cannot happen without the freedom of women.

This is brought to the surface by their own slogan Jîn, Jyîan, Azadî. Weapons, headscarves and smiles reorient the typical masculine imagery towards a war in the 2 Ist Century, the war and revolution of women. The pun frequently used to report the death of female combatants at the front (they ever 'rests in peace,' they 'rest in power') unravels the analogy and the power of the 
role played by these women and position them inside the narrative of the history of this conflict without succumbing to a romanticization of resistance (Abu-Lughod, I990).

While Öcalan's image appears as the backdrop to diverse sets of images and montages, accompanied by his words, the photographs of women are conveyed as central to the struggle and, when combined, compose a visual narrative of the conflict itself. Women from different ethnic minorities from the region, wearing military uniforms, colorful headscarves and smiling, sometimes with children and animals on wearing military clothes and carrying their wepons in the mountains, form a symbolic image that presents a new ideal parameter for representation of the Kurdish struggle. Side-by-side with their male comrades from the YPG, therefore, they mean the promotion of equality through the representation of symmetry between gender and ethnicity in the struggle for autonomy. Moreover, they evoke the territorial dimension and the region's ethnic multiplicity.

Finally, the activism of the Vietnamese and Kurdish women is also part of and influenced by various repertoires, struggles and disputes promoted by different women's movements around the world. While many committees of solidarity scattered across the continents proof the extense of this network, it is also important to lay full stress on the images and narratives of these women for the time of war conveyed transnationally aware the public to ceasefires at specific moments and in specific regions, and to the need of humanitarian corridors, for example (see Frazier, 2017; Nguy n, 2016).

Within the scope limit of the topics and issues here discussed, we concluded that making the participation of women in the war internationally visible was - and still is for in the Kurdish case - a strategy implemented by themselves through a broad and heterogenous transnational network of support and protection.

Comparing the two cases, especially in the United States and Vietnam war's case, helped catalyze and connect different feminist, anticolonial, antiimperialist and antiracist struggles in a movement that can be understood as a "manifestation of structural contradictions, aggravated by problems of conjecture" (Galvão, 20II: II2) - in this case, the war itself. In other words, by participating in the war as combatants, activists or intellectuals, women have ended up confronting, actively and interconnectedly, some of the central problems for the ideological organization of their societies.

Both cases challenge the opposition between equality and difference, making the concepts interdependent, albeit held in tension. As pointed by Joan Scott (1996), fighting for equality through the affirmation of gender difference is a key indication that women have only a paradox to offer. In this scenario, by connecting anti-systemic struggles, expressed in anti-war and anti-imperialist causes, to demands for the expansion of citizenship through recognition 
of women's rights, women activism's disputes worldviews and behaviors related to gender roles, as well as the political action related to them.

Thus, on the paths along which books, ideas and people circulate, the experiences in war are named, and the future beyond the war is imagined. Whether in local circuits or transnational networks, giving a name to acts of violence (including those that precede the outbreak of war) becomes primarily a collective practice, simultaneously a narrative and a concrete endeavour to review the substantive contents that support the imagination of the nation and the production of gender, one in relation to the other.

Received I5/5/20I9 | Reviewed 20/8/20I9 | Approved 22/8/20I9

Mariana Miggiolaro Chaguri. Ph.D. in Sociology, Associate Professor on the Department of Sociology and the Postgraduate Program in Sociology of State University of Campinas. Her main topics are related to social thought, and post-colonial studies, and recently has published the book

Rumos do Sul: a atualidade da periferia no pensamento social (with Mário

Medeiros) (2018).

Flávia X. M Paniz. MS in Sociology, Ph.D. candidate in Sociology, State University of Campinas, and research for the Middle East and Muslim World Workgroup of the Institute of International Relations of the University of São Paulo. CAPES award holder. 


\section{NOTES}

I The authors would like to thank the anonymous reviewer for their thoughtful comments and efforts towards improving our manuscript. The authors are also thankful to David Rodgers and Veridiana Domingos Cordeiro for the translation and revision of this text.

2 The museum was founded in 1987 and it is maintained by the Women's Union (WU). According to its director, Nguy $n$ Th Bích Vân, its aims are to research, collect and exhibit the culture and history of Vietnamese women and their contribution to the building of the nation and the protection of its cultural heritage and legacy (interview with Mariana M. Chaguri, 7.I.20I8). The WU was founded in I935, five years after the creation of the Communist Party of Vietnam to which it is formally linked.

3 On this topic, see Hooks, 20I7; Collins, I993.

4 On this topic, see Lorentzen \& Turpin, I998; Elshtain, I995; Waller \& Rycenga,2004.

5 The book was a result of the 'Feminism and War' conference held on October 2006 at the Department of Women and Gender Studies of the University of Syracuse (USA). Bringing together 28 researchers, both women and men, the event focused on the way in which gender issues had been mobilized in the 23 wars in which the USA had participated since the Second World War: "China (I945-1946, I950-I953), Korea (I950-I953), Guatemala (I954, I967-I969), Indonesia (I958), Cuba (I9591960), the Belgian Congo (I964), Peru (I965), Laos (I964I973), Vietnam (I96I-I973), Cambodia (I969-I970), Grenada (I983), Libya (I986), El Salvador (I980s), Nicaragua (I980s), Panama (I989), Iraq (I99I-200I), Bosnia (I995), Sudan (I998), Yugoslavia (I999), Afghanistan (200I-), and now, again, Iraq (2003-)". (Roy, cited in, Riley, Mohanty \& Pratt, 2008: 2).

6 Here we cite Benedict Anderson's definition of the nation as an imagined political community: "imagined as both inherently limited and sovereign. It is imagined because the members of even the smallest nation will never know most of their fellow-members, meet them, or even hear of them, yet in the minds of each lives the image of their communion" (Anderson, 2008: 6). In the author's argu- 
ment, the notion of "simultaneity" must work to organize time. But as Chatterjee (I993) observes in his critique of this point of Anderson's argument, "simultaneity" cannot be interpreted as a synonym of homogeneity. Instead, it is essential to take into account the heterogeneity of processes and actors that contribute - or not - to imagining the nation.

7 For the debate on mobilizing action and collective action, see Tilly, 20Io. For the debate on experience, see Scott, I998; Brah, 2006.

8 For an analysis of the participation of American women in the Vietnam War, see Marshall, I987; Norman, I990; Stur, 20 II.

9 The convergence around the WU and, consequently, the approximation with the CPV, can be explained by the fact that a significant portion of these female activists were linked to the Youth Union, led by Ho Chi Minh, the embryo of the CPV. Documents contained in folder 23 , I930/1945, archive of the Vietnamese Women's Museum.

Io This resistance led to the foundation of the Democratic Republic of Vietnam under the leadership of Ho Chi Minh.

I I Prominent female combatants during this period include $\mathrm{H}$ Th Bi (I9I6-20II), M c Th B i (I927-I95I); Nguy $n$ Th Chiên (I930-20I6), Hoàng Ngân (I92I-I949) and Võ Th Sáu (1933-1952) (see folders 23, 25, 27, 29 I947/I954; exhibition at the Vietnamese Women's Museum).

I2 The conflict was extensive in time and space, occupying both territories of Laos and Cambodia. The impact of the conflict on the US armed forces, as well as on its domestic politics, was pronounced. Official data produced by the US National Archive indicates a total of 58,2 I4 soldiers (male and female) killed in combat in Vietnam between I956 and I975 (see National Archives, 2008). On the Vietnamese side, the statistics are less precise, but there is some degree of consensus on estimating, for the same period, the total number of deaths at 2,509,000, more than I million in the north (see Rummel, 1997).

I3 These actions were organized around what became known as People's Diplomacy. For a detailed analysis of the participation of Vietnamese women in war diplomacy, see Frazier, 2017. 
I4 An association in scope, constituted by diverse local community organizations initially dedicated to assisting mothers who had lost children in combat. As the war progressed, the networks of contacts and communications organized by the women were also used by troops, helping the circulation of information or facilitating their terrestrial advances (see Giáo, 2008: 134-136). This network also organized international collaborations with campaigns like "I yen for Vietnam" promoted by the Japanese Women's Union or the Movement Against the American Invaders in Vietnam and Giving Support to Vietnamese Women and Teenagers, led by the Osaka and Tokyo Mother's Association (see folder 89, documents 345 to 389, archive of the Vietnamese Women's Museum).

I5 The first effort led by Ho Chi Minh to organize a revolutionary army dates back I94I. The decision to use violence as a counter-revolutionary instrument in the struggle for national liberation was taken during the eighth plenary session of the CPV's Central Committee. Between I94I and 1944, the army went through different names: The National Defense Brigade, the National Army of Vietnam, and finally, by decision of the Permanent Commission of the CPV's Central Committee, on December 22, I944, it became known as the People's Army (see Hòng \& Hà, 2012).

I6 On this theme, see Taylor, I999; Werner \& Huynh, 2015.

I7 The cited document, “The Kurdish Question”, was found in the Elphinston Collection, belonging to the archive of the Middle East Centre of Saint Anthony's College at the University of Oxford, published in the journal International Affairs. The documents were produced by Colonel W. G. Elphinston, an officer in the British intelligence service for the Middle East, who worked in the Jazira region between I9I8 and I9I9, having been a member of the armed British mission in Iraq between 1925 and I928, of the Quillian brigade, in Cairo, and who participated in the campaign against Rashid Ali al-Kailani in Iraq and in the British occupation of Syria and the Lebanon during the Second World War.

I8 For more information, see <https://jineoloji.org/en/>, accessed most recently November I2, 2018. 


\section{BIBLIOGRAPHY}

Abu-Lughod, Lila. (I990). The romance of resistance: tracing transformations of power through bedouin. Women American Ethnologist, I7/I, p. 4I-55.

Al-Ali, Nadje. (2007). Iraqi women: untold stories from 1948 to the present. London/New York: Zed Books.

Alexievich, Svetlana. (2018). The unwomanly face of war: an oral history of women in World War. London: Penguin Classics.

Anderson, Benedict. (2008) [1983]. Comunidades imaginadas. Reflexões sobre a origem e a difusão do nacionalismo. São Paulo: Companhia das Letras.

Badran, M. (2009). Feminism in Islam: secular and religious convergences. Oxford, England: Oneworld Publications.

Brah, Avtar. (2006). Diferença, diversidade, diferenciação. Cadernos Pagu, 26, p. 329-376. Available at <http://www. scielo.br/pdf/cpa/n26/30396.pdf>. Accessed October I3, 2019.

Butler, Judith. (20I5). Quadros de guerra. Quando a vida é passível de luto? Rio de Janeiro: Civilização Brasileira.

Chatterjee, Partha. (1993). The nation and its fragments: colonial and postcolonial histories. Princeton: Princeton University Press.

Collins, Patricia Hill. (I993). Toward a new vision: Race, class, and gender as categories of analysis and connection. Race, Sex \& Class, I/I, p. 25-45.

Das, Veena. (2007). Life and words. Violence and the descent into the ordinary. Berkeley: University of California Press.

Dirik, Dilar. (2005). Kurdish women's radical self-defense: armed and political. Published by English Telesur.

Do Thi, Van Hanh \& Brennan, Marie. (2015). Complexities of Vietnamese femininities: a resource for rethinking women's university leadership practices. Gender and Education, 27/3, p. 273-287.

Dryaz, Massoud Sharifi. (20II). Women and nationalism: how women activists are changing the Kurdish conflict. The Middle East. Ph.D. students conference at SOAS. State, society, and economy in the Modern Middle East. 
Elphinston, W.G. (2009) [1946]. The Kurdish question. International affairs, 22/I, p. 9I-I03.

Elshtain, Jean Bethke. (I995). Women and war. Chicago: University of Chicago Press.

Frazier, Jessica M. (2017). Women's antiwar diplomacy during the Vietnam War era. Chapel Hill: The University of North Carolina Press.

Galvão, Andréia (20II). (20II). Marxismo e movimentos sociais. Crítica Marxista, 32, I07-I26.

Giáo, Mai Quynh. (2008). Everlasting memories. Hanói: Women' Publishing House/The Vietnamese Women's Museum.

Heper, Metin. (2007). The State and Kurds in Turkey: the question of assimilation. New York: Palgrave Macmillan.

Hòng, Trinh Vuong \& Hà, Nguyen Manh. (2012). How the Vietnamese people's Army was founded. Hanói: The Guói Publisher.

Hooks, Bell. (20I7). Ensinando a transgredir: a educação como prática da liberdade. São Paulo: WMF Martins Fontes.

Kowarsch, Ann-Kristin \& Kilic, Nursel. (2007). Psychological consequences of trauma experiences on the development of Kurdish migrant women in the European Union. Final results and background of a survey in five European countries and Turkey. Rotterdam: International free women's foundation.

Logevall, Fredrik. (2018). Why Lyndon Johnson dropped out. The New York Times. Available at <https://www.nytimes.com/2018/03/24/opinion/lyndon-johnson-vietnam. html>. Accessed October 20, 2018.

Lorentzen, Lois Ann \& Turpin, Jennifer E. (I998). The women and war reader. New York: NYU Press.

Marshall, Kathryn. (1987). In the combat zone: an oral history of American women in Vietnam, I966-I975. Boston: Little Brown.

Mojab, Shahrzad. (200I). The solitude of the stateless: Kurdish women at the margins of feminist knowledge. In: Women of the non-state nation: the Kurds. Costa Mesa: Mazda publishers, P.I-22. 
National Archives. (2008). Vietnam Conflict Extract Data File. Vietnam War U.S. Military Fatal Casualty Statistics. Available at <https://catalog.archives.gov/id/2240992>. Accessed on October 3I, 2018.

Nguyễn, Lien Hang. (2017). North Vietnam had an anti-war movement, too. The New York Times. Available at <https:// www.nytimes.com/2017/08/25/opinion/north-vietnamhad-an-antiwar-movement-too.htm $>$. Accessed October 20, 2018.

Nguyễn, Thị Bích Vân. (20I8). Entrevista a Mariana Miggiolaro Chaguri, Hanói.

Nguyễn, Việt Thành. (2016). Nothing ever dies. Cambridge, MA: Harvard University Press.

Norman, Elizabeth M. (1990). Women at war: the story of fifty military nurses who served in Vietnam. Philadelphia: University of Pennsylvania Press.

Perrot, Michelle. (1998). Mulheres públicas. São Paulo: Editora Unesp.

Riley, R. L.; Mohanty, C. Talpade \& Pratt, M. Bruce. (2008). Feminism and war: confronting US imperialism. London: Zed.

Rummel, R. J. (I997). Statistics of Vietnamese democide estimates, calculations, and sources. Statistics of democide. Charlottesville: Center for National Security Law, School of Law, University of Virginia.

Scott, Joan. (I998). A invisibilidade da experiência. Projeto História, I6, p. 297-325. Available at <https://revistas. pucsp.br/index.php/revph/article/view/I I I83/8I94>. Accessed on October I8, 2018.

Scott, Joan. (1996). Only paradoxes to offer: French feminists and the rights of man. Cambridge, MA: Harvard University Press.

Scott, Joan W. (I986). Gender: a useful category of historical analysis. The American Historical Review, 9I/5. Available at <www.jstor.org/stable/I864376>. Accessed on October I8, 2018.

Scott, J. W. \& Keates, D. (2004). Going public: feminism and the shifting boundaries of the private sphere. Urbana: University of Illinois Press. 
Strohmeier, Martin. (2003). Crucial images in the presentation of a Kurdish national identity: heroes and patriots, traitors, and foes. Leiden: Brill Academic Publishers.

Stur, Heather Marie. (20II). Beyond combat: women and gender in the Vietnam war era. Cambridge, UK: Cambridge University Press.

Taylor, Sandra C. (1999). Vietnamese women at war: fighting for Ho Chi Minh and the revolution. Lawrence: University Press of Kansas.

Tilly, Charles. (2010). Regimes and repertoires. Chicago: University of Chicago Press.

Waller, Marguerite \& Rycenga, Jennifer. (2004). Frontline feminisms: women, war, and resistance. New York: Routledge.

Werner, Jane. (2009). Gender, household, and state in post-revolutionary Vietnam. New York: Routledge.

Werner, Jayne \& Huynh, Lu Doan. (2015). The Vietnam War: Vietnamese and American perspectives. New York: Routledge. Yavuz, M. H. (2004). Provincial ethnic federalism in Iraq. Middle East Policy, II/I, p. I26-I3I.

Yildiz, Kerim (2005). The Kurds in Syria: the forgotten people. London: Pluto Press in association with Kurdish Human Rights Project. 


\section{A GUERRA DAS MULHERES: ATIVISMOS DE GÊNERO NA GUERRA DO VIETNÃ E NAS GUERRAS PELA AUTONOMIA DO CURDISTÃO}

\section{Resumo}

Este artigo problematiza a participação e debate o ativismo de mulheres em dois eventos: a Guerra do Vietnã (I954I975) e as guerras pelo Curdistão (I923 em diante). Como hipótese, sustentamos que tais lutas podem ser lidas a partir do esforço comum de tornar inteligível e nomear um conjunto variado de experiências que, reorganizadas a partir ou em função do conflito armado, produzem novas mediações entre gênero e nação. $O$ artigo está dividido em três partes: nas duas primeiras, são apresentados aspectos dos dois conflitos apontando eventuais convergências e diferenças; na sequência, observam-se as variadas formas de participação e de ativismo de mulheres existentes nos dois casos; finalmente, são debatidas as interfaces entre a produção do gênero, da guerra e das ideias, percorrendo uma multiplicidade de narrativas, experiências e relatos que apontam para a dimensão heterogênea das guerras, das nações e, portanto, do regime de ideias que deve acompanhá-las.

\section{WOMEN'S WAR: GENDER ACTIVISM IN THE VIETNAM WAR AND IN THE WARS FOR KURDISH AUTONOMY} size that the reorganization of gender roles during the conflicts marks the meanings of wars and configures what we call a woman for the times of war, that is, a woman who transits across the spaces of public confrontation, armed conflict and domesticity. The approach outlined here is structured into three parts: the first and the second ones present aspects of both conflicts by pointing to possible convergences and differences between them; we also present the variety of networks of participation and activism of women in both cases. In the third and final part, we discuss the interfaces among the production of gender, war, and ideas, crossing a manifold of narratives, experiences, and stories that reveal different dimensions of wars and nations, and the diversity of the regimes of ideas that attached to them.

\section{Palavras-chave}

Gênero;

guerra;

nação e nacionalismo;

feminismo pós-colonial.

\section{Keywords}

Gender;

war;

nation and nationalism; post-colonial feminism. 